\title{
Contribution of Management Commitment in Industrial Waste Management: Impact on Waste Minimazation
}

\author{
Lidya E. Simanjuntak ${ }^{1, *}$, Tri Edhi Budhi Soesilo ${ }^{1}$, and Herdis Herdiansyah ${ }^{1}$ \\ ${ }^{1}$ School of Environmental Science, Universitas Indonesia, Salemba, Indonesia
}

\begin{abstract}
Industrial development in the process can have an impact on the environment. The focus of this research is surfactant plant in West Java which has certify for ISO 14001:2015 certified on Environmental Management System. This study aims to evaluate management commitment in environmental management, and commitment management in implementation of waste minimization program. The research method used is a quantitative methods, with observations and reinforced by questionare to workers in the study sites, used secondary data and reference data. Likert scale is used to measure employee attitudes and ultimately categorization. The empirical evidence shows that employee knowledge and attitudes in waste management are good enough, contrary to waste reduction. In the future recommendations, it is necessary to set waste reduction targets in the key performance index (KPI) per department and evaluation per semester or year in achieving targets.
\end{abstract}

\section{Introduction}

The surfactant industryis an industry that plays an important roletoday, where human daily needs human needs surfactant in supporting its activities. The focus of this research on the management of surfactant industry waste that operates in PT X. Currently, PT.X has ISO 14001 certified on Environmental Management System. This study aims to evaluate management commitment in environmental management, andevaluate commitment management in implementation of waste minimization program. Surfactants are chemicalproductsproduced by PT.X. The resulting derivative products are Sodium Lauryl Sulphate (SLS) and Sodium Lauryl Esther Sulphate (SLES), both of which are act as surface tension reducers in shampoo making industry, soap, and tooth paste. In the operational activities of the company is supported by internal resources in the form of utility facilities production machines both continuous process and batch process.

The rapidly growing industry to day is the surfactant industry. Surfactants are a major component in detergents and have a difficult natural chemical (degraded) chemical chain. Surfactant-owned surfactants have the potential to reduce surface tension, and improve the stability of the emulsion system. This makes surfactants widelyused in various industries,

\footnotetext{
*Corresponding author: khalida@utm.my
} 
such as soap industry, detergents, cosmeticsproducts, personal care products, pharmaceuticals, food, coating paints, paper, textiles, mining, petroleum industries, and soforth.

PT X already has an environmental management program, but an evaluation of the minimization program needs to be done to achieve a sustainable industry. According to the United Nations Environmental Program waste minimization is a strategy aimed at preventing the emergence of waste through interventions in the up stream process. In the production process, the strategy focuses on optimizing material resources and energy use and reducing the use of toxic-containing raw materials. Waste is one of the indicators of efficiency, sothat efforts can be made is the reduction of waste from sources and utilization that is formed through recycling.

The goal of reducing waste at the source is to reduce the amount and toxicity of the material to bemanaged by preventing the appearance of waste. In general, the waste reduction stream from the source is reduce or eliminate the amount or toxicity of the materials used in the manufacture and packaging of products, redesigning (re-design) the product to increase product life, product can be reused and product can be repaired changing purchasing mechanisms in an effort to minimize waste toxicity and loads,modify the pattern of product consumption and use of materials in an effort to reduce the amount and waste generated.

According to the National Environment Agency Singapore several stages in the application of industrial waste minimization are obtaining commitment from organizational management, determine the work team in the waste minimization program,conduct waste audits, determine the actual cost of waste, develop waste reduction alternatives, conduct a scope assessment of the saving from waste reduction and rank for the choice of austerity programs, develop a waste minimization work plan, and mplement and improve the work plan

Good corporate commitment in environmental management has a positive impact on the work environment and the environment around the work place. According to the International Institute for sustainable development, empirical evidence suggests that companies that have done $4 \mathrm{R}$ (reduction, reuse, recycling and recovery) can then cut costs and save profits. An industry can be said to have run the Clean Technology Process, if from the beginning the industry has thought of ways to minimize its waste, starting from selection and handling of raw materials, designing factories with $4 \mathrm{R}$ principles, choosing clean and energy-efficient process technologies. In the production process a company has made a wastereduction or zerowasteapproachthen the company has gained the main advantage in implementing sustainability in its business .

Table 1. Production Volume, Total Waste, Electricity, Water and Steam Consumption

\begin{tabular}{|c|c|c|c|c|c|c|}
\hline & Unit & $\mathbf{2 0 1 3}$ & $\mathbf{2 0 1 4}$ & $\mathbf{2 0 1 5}$ & $\mathbf{2 0 1 6}$ & $\mathbf{2 0 1 7}$ \\
\hline $\begin{array}{c}\text { Production } \\
\text { Volume } \\
\text { Total } \\
\text { hazardous } \\
\text { waste } \\
\text { Consumption } \\
\text { of electricity }\end{array}$ & $\mathrm{MT}$ & 32.643 & 37.937 & 44.110 & 52.858 & 50.917 .5 \\
\hline $\begin{array}{c}\mathrm{kWh} / \mathrm{ton} \\
\text { product }\end{array}$ & 196.00 & 196.10 & 189.70 & 162.00 & 142.00 \\
\hline $\begin{array}{c}\text { of water } \\
\text { of wamption }\end{array}$ & $\begin{array}{c}\mathrm{m}^{3} / \text { ton } \\
\text { product }\end{array}$ & 3.78 & 3.50 & 3.13 & 2.56 & 2.50 \\
\hline of steam & $\begin{array}{c}\text { ton/ton } \\
\text { product }\end{array}$ & 0.36 & 0.31 & 0.23 & 0.21 & 0.18 \\
\hline
\end{tabular}


From Table 1 above, it can be seen that the highest production was in 2016, which amounted to $52.858 \mathrm{MT}$, but the highest amount of hazardous waste produced was not in 2016 but in 2015 as much as 499.80 MT. Contrary, viewed from the highest electricity and steam electricity consumptionin 2013, consumption of electricity was $196 \mathrm{kWh} / \mathrm{ton}$ product, consumption of water $3.78 \mathrm{~m}^{3} /$ ton product and consumption of steam 0.36 ton/ton product. The highest amount of hazardous waste produced from sulphonic reject (off specification quality). This result indicates a gap between the volume of production and the waste produced.

\section{Materials and Methods}

The approach to be used in this research is quantitative approach. Quantitative approach is chosen because research that will be done requires a systematic and measurable research . The method used is a quantitative with questionnaires as instrument to evaluate management commitment in the management of the surfactant industry waste. Respondents in the study were employees who worked at PT. X. The number of employee samples is determined by the Slovin method which is 56 people from total population 100 people.

\subsection{Measure and Scale}

The instrument used to measure each of the variable in this study consisted of three parts. The first section present the respondent about their demographic information such as gender, age , education level, department and working time period.

The second section is to ask them about their knowledge about environment waste management system based on company procedure, the research was carried out based on optional questions. If more than $50 \%$ of the total score is correct then it can be said that the employee's knowledge of waste management is quite good.

The last section for measure employee attitudes towards waste management programs. In this part we use Likert scale. The above items were evaluated with a 4-point scale from "Strongly agree (4) to "Strongly disagree" (1). Then the categorization of results into three, namely good, sufficient and not good.

\section{Results and Discussions}

PT. X has been operating since 1983 until now. In its operational activities, PT X has implemented an integrated management system covering ISO 14001: 2015 environmental management system. At present PT X is in normal operation stage. The main activityis the production process of basic chemicalswith the main products are Sodium Lauryl Sulfate (SLS) and Sodium Lauryl Ether Sulfate (SLES), both of which are the act of lowering the surface tension in shampoomakingindustry, soap, and toothpaste.

Observations were made in the field to see the implementation of environmental management by PT. X. Management that currently exists at PT. X Basically PT. X has carried out an environmental management program.

\subsection{Waste Management Conditions in PT.X.}

Below is an environmental management program that has been carried out by PT. X 


\subsubsection{Air quality and Noise management}

In an effort to ensure the quality of a good working environment and reduce the possible negative impacts related to operational activities, PT X reduce emissions from pollution sources by operate scrubber at $\mathrm{SO}_{3}$ Plant to reduce $\mathrm{SOx}$ emission, operate the dust collector in the TTD area to reduce dust exposure in the work environment, periodically preventive maintenance of utility facilities to reduce exhaust emissions $\left(\mathrm{CO}_{2}, \mathrm{SOx}, \mathrm{NOx}\right)$, install the insulation in the compressor and generator sets to reduce noise exposure, install 'silencer' on the diaphragm pump to reduce noise exposure, preparation of work procedures related to the management of the Work environment, reuse of ammonia from production.

\subsubsection{Surface Water Quality Management}

Ensuring surface water quality, the PT. X conduct a 'batch process release' of waste water treatment results to ensure the quality of the waste process waste discharged to the receiving body meets the specified quality standard.Conduct daily inspection on WWTP performance, at each stage of wastewater treatment to ensure the results of wastewater preparations meet the established quality standards, provide temporary shelter / protection system against possible chemical spill of "pit and bundwall" and preparation of work procedures related to the management of the work environment.

\subsubsection{Hazardous Waste Management}

For hazardous waste management, segregation/grouping of waste by its hazard category (hazardous and non hazardous waste) was done, provide a separate storage area for hazardous and non hazardous waste, documenting all types of waste generate, in cooperation with relevant parties approved by the government in the utilization, processing and transportation of hazardous waste and prepare of work procedure srelated to the management of Environment and Waste (Waste \& Environment Management system)

\subsubsection{Waste Water Treatment Management}

For waste water treatment management they provide temporary shelter/protection system against possible chemicals pill of "pit and bundwall", conductdaily inspection on WWTP performance, at each stage of waste water treatment to ensure the results of waste water preparations meet the established quality standards. And categorize the type of waste water intoseveral groups, related to the handling process.

\subsubsection{Traffic Management}

Monitoring the flow of traffic in the area of PT. X, conducted to determine the level of density at the location of PT. X, daily recording is done for all types of vehicles that go out $\&$ enter the area. 


\subsection{Reliability and Validity Assessment}

Realibility and validity are carried out before the questionnaire is distributed to respondents. Test of reliability and validity is carried out in the section 3 question. For validity test with BivariatePearson, based on the test results obtained results of $r=0.74$ with $\mathrm{r}$ table $=0.71$ with $\alpha=0.05$ and because of $\mathrm{r}>\mathrm{r}$ table, so that it can be said that the questionnaire used in section 3 attitude assessment is valid. For realibility test with Alpha Cronbach, $r=0.855$ with $r$ table $=0.533$ with $\alpha=0.05$ because of $r>r$ table concluded the questionare is reliable.

\subsection{Management Contribution}

Analysis section 1, Respondent Demographics

After we confirm that all the transactions are reliable and valid in the first stage, the next step is to distribute the questionaire to 56 respondents. First is to look at the demographic distribution of respondents. With the following results.

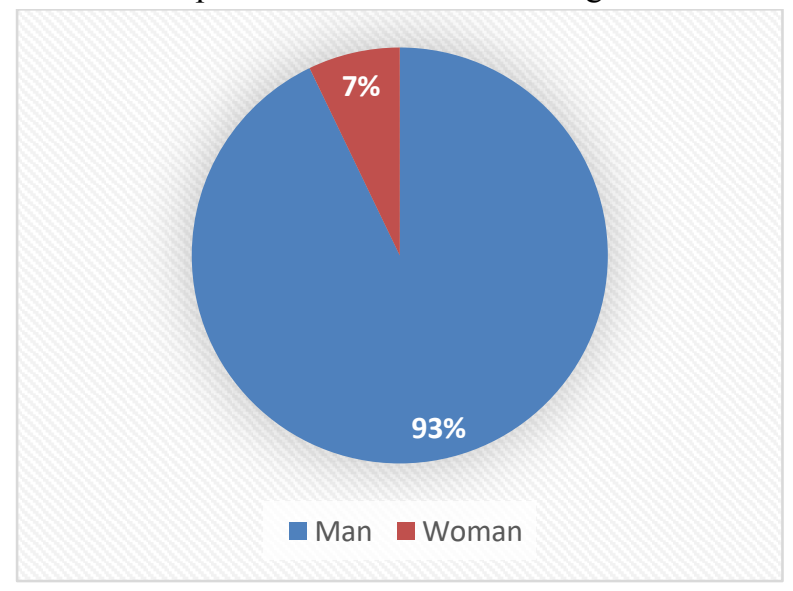

Fig. 1. Profile of Respondents Based on gender

Total respondentsis $93 \%$ of respondents were male, this this because most of the employee working in shift as operator. The respondents came from security, warehouse, quality control, application labs, production, lab applications and production. 


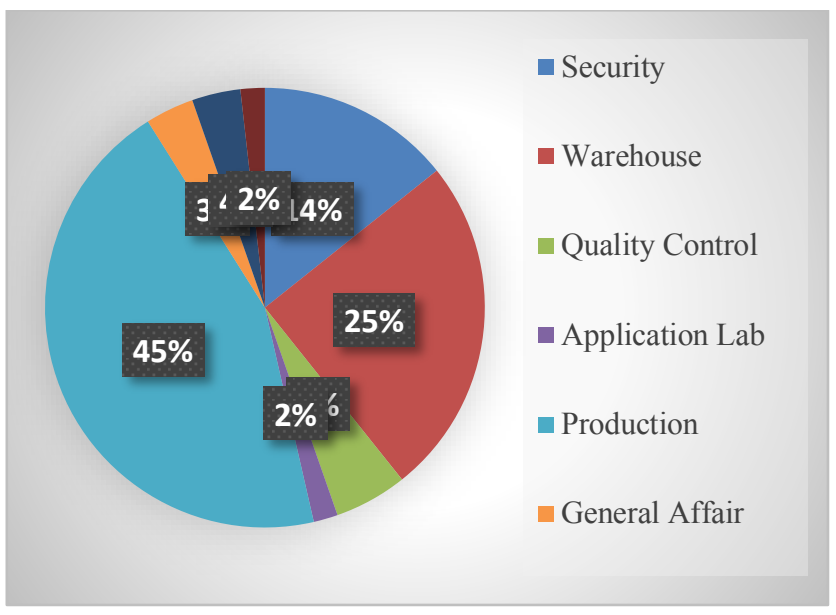

Fig. 2. Profile of Respondents Based on Department

Based on working period in the company, it can be seen that $46 \%$ of respondents work the most for 5-10 years.

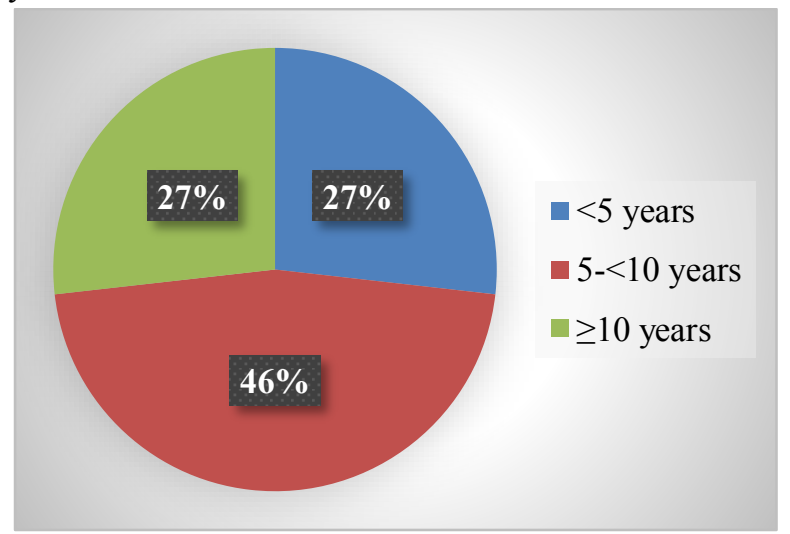

Fig. 3. Profile of Respondents Based on Working Period

The education level of the majority respondents is high school graduates, as much as $86 \%$. 


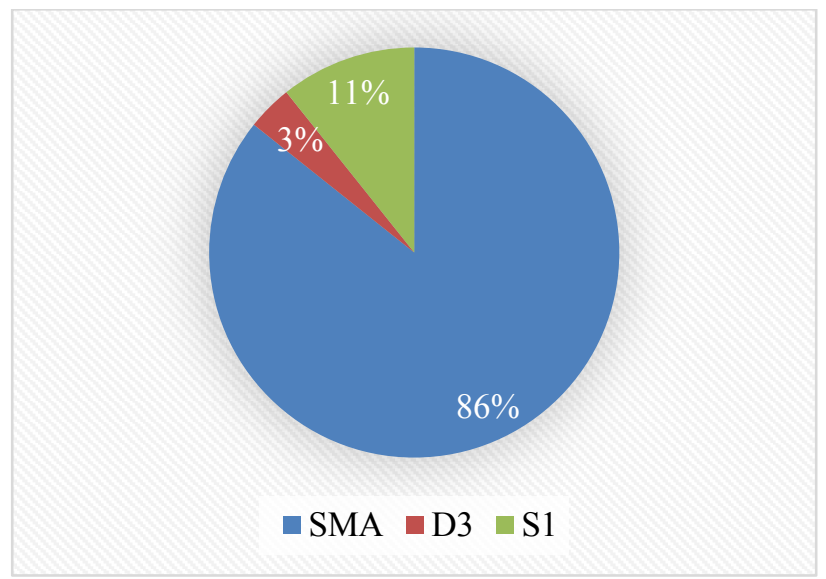

Fig. 4. Profile of RespondentsBased on EducationalBackground

Section 2 analysis, Measuring Employee Knowledge About Waste Management.

The series of questions were given to employesswith the option to measure employee knowledge about waste management. The material used comes from existing procedures. Questions raised regarding understanding of environmental policies in the company, environmental management programs, knowledge of hazardous waste and its handling, evaluation of standard waste management targets for personal protective equipment used in handling waste and emergency drill programs if there's a chemical spillage. The result shows from 56 respondents, the final score was $64 \%$. So it can be said that respondents have good knowledge about waste management.

Analysis section 3, Measuring Employee Attitudes

Employee attitudes are measured by a series of statements. Scale is given from agreeing to strongly disagreeing. There are 15 statements given to respondent and below the summary result.

Tabel 2. Scoring for all question for section 3 analysis.

\begin{tabular}{|l|c|l|c|}
\hline Total Score & 2672 & \multicolumn{3}{|c}{} \\
\cline { 1 - 2 } Maximum & 3360 & \multicolumn{2}{|c}{} \\
\cline { 1 - 2 } Minimum & 840 & & \multicolumn{2}{|c}{ Good } \\
\hline Interval & $840-1680$ & $1681-2521$ & $2521-3360$ \\
\hline Criteria & Poor & Moderate & Good
\end{tabular}

Based on the results of the study found that the overall value is 2672 . Where the final results are categorized as "Good". Research on management commitments has been carried out by Hirunyawipadaet al., 2018, "Corporate environmental commitment and financial performance: Moderating effects of marching and operation capabilities", this study reveals corporate environmental commitment, can improve profitability and forward looking value for firms with strong capability. The role of environmental management accounting by Latan et al. reveals the effect of environmental strategy, environmental uncertainty and top management on corporate environmental performance, that there is a positive and significant influence between corporate environmental strategies, top management commitment and environmental uncertainty on the use Environmental Management Accounting (EMA) in turn can improve the environmental performance. But 
this research reveals evaluation of management's commitment to the workplace environment is good, which measured through the knowledge and attitudes of employees, contrary the minimization program has not run optimally. This can be seen from the data of the last five years where, at the highest volume production in 2016, the highest amount of hazardous waste produced in 2015.

\section{Conclusion}

PT. X has carried out environmental management such as air quality and noise management, surface water quality management, hazardous waste management, wastewater treatment management and traffic management. However, for minimization of waste in the last five years it has not shown optimal results. Testing on aspects of knowledge and attitudes of employees shows that management commitment is good in managing the working environment of the employee. But the minimization target has not been included in the department's annual target. So that the absence of targets in waste minimization is one of the contributing factors in the last five years the company has not reached optimal minimization conditions.

\section{Acknowledgments}

This research is funded by the Grant of Indexed International Publication For Final Project of Student PITTA Universitas Indonesia with Contract Number: 2586/UN2. R31/HKP.05.00/2018.

\section{References}

1. Ahsan, S. J. Clean Technology Enviroment Policy 7 (2005)

2. Azo Cleantech. Diminishing or eliminating of waste is the main advantage of implementing sustainable development in business. https://www.azocleantech.com/news.aspx?newsID=21687 (2018)

3. Bradley \& Engar. Environmental science (Mcgraw Hill, 2009)

4. Brunner, P.H. \& Rechberger, H. Practical handbook of material flow analysis (Lewis Publishers, New York, 2004)

5. Boer, J. J. Procedia Technology 22 (2016)

6. Chantraine, F. Journal of Surfactan and Detergent 12 (2009)

7. Cunnningham, W. Environmental science. Mcgraw Hill (2007)

8. Chiras, D. Environmental Science $\left(9^{\text {th }}\right.$ ed.). (Burlington, United States: World Headquarters, 2013)

9. Harunyawipada, T. Xiong, G. Journal of Business Research 86 (2018)

10. Hamdoun, M. Jabbour,C. Othman, H. Journal of Cleaner Production. 193 (2018)

11. International Institut for Sustainable Development. The 4R-reduction, reuse, recycling and recovery. https://www.iisd.org/business/tools/bt 4r.aspx, 4 March 2018 (2013)

12. Latan, H. Jabbor, C. Jabbour, A. Wamba, S. Shahbaz, M. Journal of Cleaner Production 180 (2018)

13. Liu,W., Yuan, HP. Investigation waste reduction potential in upstream processes of offshore prefabrication construction (The University of Hongkong, 2013) 
14. National Environment Agency. Guidebook on waste minimisation for industries. (Singapore, 2012)

15. Miller, G. T. \& Spoolman. Environmental science (Fitzgerald, Graphic World Inc , 2015)

16. Metcalf, \& Eddy, Wastewater engineering, treatment, disposal, and reuse, third edition (New York, McGraw-Hil, Inc,1991)

17. Rao, M.N, Waste water treatment (Oxford \& IBH Publishing Co. Pvt. Ltd. New Delhi. Bombay Calcuta, 1978)

18. Savarino. P, Motoneri. G, Musso. G, Boffe. V. Journal Surfactant Detergent. 13 (2010)

19. Othman. S, Noor. Z, Abba. A, Yusuf. R. Journal of Cleaner Production. 41 (2018)

20. Scheibel J. Journal of Surfactan and Detergent 7, 5 (2004)

21. Seadon, J. Journal of cleaner production 18 (2010)

22. Tchobanaglous, G., \& Burton, F. L. Wastewater engineering, third edition (New York, Mcgram-Hill (1991)

23. Wagner, E. Upgrading water treatment plants. London (Spon Press, 2001) 